\title{
NOT SO IDLE THOUGHTS ABOUT EIDOLOTHUTON
}

\author{
Ben Witherington III
}

\section{Summary}

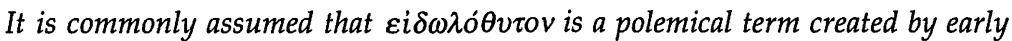
Jews to refer to meat sacrificed to a pagan god. An exhaustive search of the data in the TLG and in the papyri casts doubts on this hypothesis. All of the references to

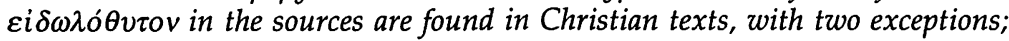
and both of these exceptions may have been influenced by Christian redaction. In any case, it appears that neither of these texts antedates the Corinthian correspondence. Thus, this term may have originated in early Jewish Christianity.

$A$ study of all the NT references to ei $\delta \omega \lambda$ ó $\theta v \tau o v$ reveals that this term

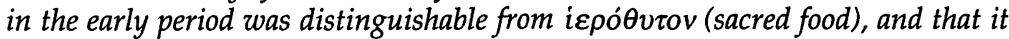
meant meat sacrificed to and eaten in the presence of an idol, or in the temple

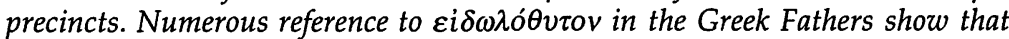
Chrysostom and others understood this to be the meaning of the term in Acts 15 and in other contexts.

Several possible implications of the above are: (1) the Decree in Acts 15 is about Gentiles refraining from meals and immorality in pagan temples, not about them keeping a modicum of Jewish, or Noachic food laws; (2) 1 Cor. 8-10 reflects Paul's acceptance and implementation of the Decree; (3) Galatians was written before the Decree and reflects the struggle that led to the Decree; (4) Paul and James were in basic agreement in regard to what Gentiles needed to do to maintain table fellowship with Jewish Christians-avoid pagan feasts and immorality. Neither imposed circumcision or food laws on Gentiles. The latter was the position of the Judaising faction in the Jerusalem Church who were more conservative than James, Peter, or Paul. As C. Hill's recent 'Hellenists and Hebrews' shows, F.C. Baur's view of early Christianity is no longer adequate.

\section{Introduction}

It has become a commonplace of New Testament scholarship that the term $\varepsilon i \delta \omega \lambda$ ó $\theta v \tau o v$, usually translated 'idol meat', is as $\mathrm{H}$. Conzelmann says 'a Jewish term, constructed with a polemical edge against the Greek icpó $\theta v \tau o v^{\prime} .{ }^{1}$ Yet so far as I can tell no one has in fact carefully studied the various occurrences of this word in the relevant sources to see whether such a conclusion is warranted. It is now possible with the help of

${ }^{1}$ Cf. H. Conzelmann, 1 Corinthians (Philadelphia, Fortress 1975) 139; G.D. Fee, The First Epistle to the Corinthians (Grand Rapids, Eerdmans 1987) 357 n. 1 'a word that comes from Hellenistic Judaism'. 
Ibycus and the TLG as well as supplementary sources now on $C D$ to study this matter in a way that is more scientific and exhaustive. 2 This sort of study leads to some very surprising conclusions indeed.

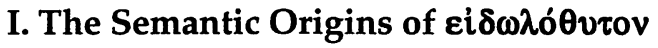

In some cases the absence of data is as significant as its presence and this is certainly true of $\varepsilon i \delta \omega \lambda$ ó $\theta v \tau o v$. In the Greek sources that antedate Paul's letter now called 1 Corinthians,

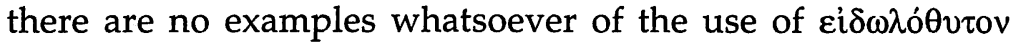
except possibly 4 Maccabees 5:2 or Sibylline Oracles 2:96, and this is very uncertain. In addition to this there are no examples from any papyri, any inscriptions, or any of the Coptic sources for the use of this term at all. Furthermore, outside Christian literature there are only the two aforementioned references to

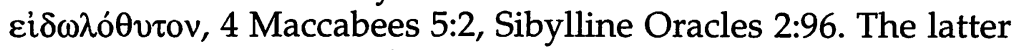
text seems clearly to reflect Christian influence (compare $\alpha i \mu \alpha$ $\delta \dot{\varepsilon} \mu \grave{\eta} \phi \alpha \gamma \varepsilon \dot{\varepsilon} \varepsilon v, \varepsilon \dot{i} \delta \omega \lambda \circ \theta \dot{v} \tau \omega \nu \delta^{\prime} \alpha \dot{\alpha} \varepsilon \dot{\varepsilon} \chi \sigma \theta \alpha \imath$ with Acts 15:29

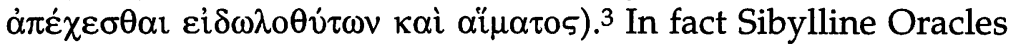
2:96 is found in only one manuscript, which the experts say is based on Ps-Phocylides Sententiae 31, which in turn is derived from Acts 15:29.4 In regard to the former text in 4 Maccabees, it may be dated as early as $63 \mathrm{BC}$ but is usually thought to have been written somewhat after that (i.e., between AD 63-70). Nevertheless, scholars admit it could be dated after the Hadrianic persecutions in the second century AD. ${ }^{5}$ In short, there

2I gratefully acknowledge the free access given to me by Tyndale House to Ibycus, the TLG, and the disks including all the papyri and inscriptions that made this work possible. I am also grateful to the people at Ibycus, Duke, and elsewhere who provided the necessary technology and data bases.

3J.J. Collins points out that the Christian redaction of Book 2 of the Oracles took place in the second century, no later than AD 150; cf. J.H. Charlesworth (ed.), The Old Testament Pseudepigrapha Vol. I (New York, Doubleday 1983) 332.

${ }^{4} \mathrm{D}$. Young (ed.), Theognis, Ps-Pythagoras, Ps-Phocylides (Leipzig, Teubner 1961) 100; cf. also P. van der Horst, The Sentences of Pseudo-Phocylides (Leiden, Brill 1978) 135-6.

${ }^{5} \mathrm{Cf}$. H. Anderson, '4 Maccabees' in J.H. Charlesworth (ed.), The Old Testament Pseudepigrapha Vol. II (New York, Doubleday 1985) 533-4. Anderson concludes it was written outside Palestine probably shortly 
is no certain evidence that the term $\varepsilon i \delta \omega \lambda$ ó $\theta v \tau o v$ was used prior to 1 Corinthians at all. It has sometimes been suspected that 4 Maccabees has undergone some Christian revisions, and if this is correct, it is not even certain that we have any examples of

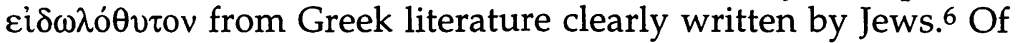
the 112 references to $\varepsilon i \delta \omega \lambda$ ó $\theta v \tau o v$ that the TLG can produce all but two are clearly from Christian sources; and of these remaining two one is very likely to derive ultimately from a Christian source, while the other is possibly from a Christian hand.7 There is, then, probably no warrant for the conclusion of Conzelmann quoted above. Certainly, one can make no dogmatic statements in this direction on the basis of one or two doubtful examples.

We must conclude this section of our discussion as

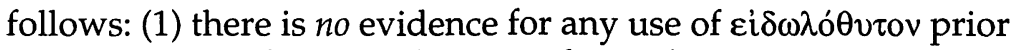
to the writing of 1 Corinthians in the mid 50s AD, not even in whatever Greek translation of the Hebrew Scriptures Paul may have known and used; (2) apart from one possible exception, it appears that $\varepsilon i \delta \omega \lambda$ ó $\theta v \tau$ ov was not a term used by Jews about pagan practices, but rather originated as a pejorative JewishChristian term, possibly even coined by the Christian Jew Paul.

\section{The Semantic Range of $\varepsilon i \delta \omega \lambda o ́ \theta v \tau o v$}

In regard to the meaning of $\varepsilon i \delta \omega \lambda \theta^{\prime} \theta v \tau o v$ most commentators,

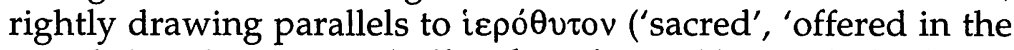
temple') and $\theta \varepsilon$ ó $\theta v \tau o v$ ('offered to the god'), conclude that it literally denotes something sacrificed to an idol or idols. That it is a polemical term no one doubts. The fact that in all the vast corpus of Greek literature, papyri, and inscriptions it is never found outside of Christian and one Jewish source is surely eloquent testimony to its provenance. It is not a term pagans would have coined or used.

It is worth pondering whether $\varepsilon i \delta \omega \lambda$ ó $\theta v \tau o v$ might be the negative counterpart to Corban (cf. Mk. 7:11) which of course means something dedicated to the true God, and placed

before the fall of the Temple, but certainly no earlier than $63 \mathrm{BC}$. However, he admits that a date after the Hadrianic persecutions is quite possible.

6On Christian interpolations in 4 Maccabees, see Anderson, '4 Maccabees', 539ff.; though Anderson doubts such Christian interpolations.

7The evidence does not allow us to say 'probably' about the reference in 4 Maccabees. 
in the Temple in Jerusalem for that purpose. ${ }^{8}$ If this is so, then the connection with the Temple may be more important than is sometimes thought. We will return to this point.

In regard to what $\varepsilon i \delta \omega \lambda$ ó $\theta v \tau o v$ is assumed to connote, it is usually thought to mean nothing more than 'idol meat' wherever and whenever it may have been consumed. It appears to me that this assumption is a mistake, indeed a large one, and it has caused exegetes no end of difficulties making sense of 1 Corinthians 8-10 and of the so-called Apostolic

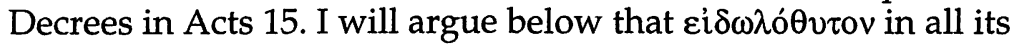
1st century $\mathrm{AD}$ occurrences means an animal sacrificed in the presence of an idol and eaten in the temple precincts. It does not refer to a sacrifice which has come from the temple and is eaten elsewhere, for which the Christian sources rather use the term iepó $\theta v \tau o v$. In fact in all the 1st century $A D$ references the association of $\varepsilon i \delta \omega \lambda$ ó $\theta v \tau$ vo specifically with temples and eating seems very likely and is made clear by the context of these references in one way or another.

\section{The Substance of the Argument}

\section{1st Century AD References outside the NT}

We will begin this section of the discussion by looking first at the non-New Testament references, just in case they do in fact provide evidence for a non-Christian and earlier use of the term. The reference in 4 Maccabees 5:2 describes the misdeeds of the tyrant Antiochus. We are told that he ordered his troops to drag 'every single one of the Hebrews' to 'a certain high place' where he was seated with his counsellors and to compel the Hebrews to eat pork and $\varepsilon \dot{i} \delta \omega \lambda$ ó $0 \tau \tau$ ov. What is important about this story is the locale: 'a certain high place'. It is quite clear that whoever wrote 4 Maccabees was a person deeply influenced by the Hebrew Scriptures for whom the phrase 'a high place' (bamah in Hebrew) had a very clear association with pagan worship, especially in light of the polemic of the later prophets such as Ezekiel. The references are too numerous to mention them all but one should especially consider Numbers 33:52; 1 Kings 12:28-33 (calf worship) and 13.2, 3; 2 Kings 17:718 , 29; 2 Chronicles 21:11; 31:1; Isaiah 15:2; 16:12, Jeremiah 48:35; Ezekiel 6:3; 16:24, 25, 31, 39; Hosea 10:8; Amos 7:9. Thus,

${ }^{8} \mathrm{On}$ the matter of Corban, see my Women in the Ministry of Jesus (Cambridge, CUP 1984) 12-13. 
Antiochus was not merely trying to force the Hebrews to eat non-kosher food, he was trying to force them to do it in a setting where it would obviously carry the clear connotations of participating in an act of idol worship. ${ }^{9}$

The reference in the Sibylline Oracles is part of one of many passages in these oracles excoriating idolatry. The specific prohibition of 'eating blood' coupled with the term

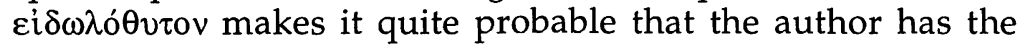
image of eating in the temple in mind, where the blood might be poured out and consumed, or at least would still be sufficiently in the meat that it would be consumed with the term ci $\delta \omega \lambda$ ó $\theta$ vov. ${ }^{10}$ Meat sacrificed in the temple but later sold to or taken to the macellum (meat market) would probably not have so close an association with the consumption of blood. In its context this piece of advice is either an isolated admonition or it is connected to 2:95 where one is warned against drinking in excess. J.J. Collins separates it from 2:95, arguing that 2:95 is the conclusion of a preceding parenthetical remark. ${ }^{11}$ In any event, this isolated reference in the Sibylline oracles does not

${ }^{9}$ Since the entire context of the discussion in 4 Mac. 5 is about eating pork as a meat forbidden in Torah and not about idol meat, and since the word 'idolatry' does not appear in the context anywhere, the suggestion is ready to hand that the phrase 'and idol meat' is a Christian gloss.

10It has been pointed out to me that drinking blood was not a part of Greek ritual, and that the Greeks saw this as the practice of barbarians and marginalised groups; $c f$. W. Burkett, Greek Religion (Cambridge, Harvard University Press 1985) 55-60. This is true enough, but two things need to be said in response: (1) Paul is talking about Roman practices in Roman Corinth, not Greek practices. It cannot be stressed enough that the Corinth Paul knew was a Roman colony, rebuilt to cater to Roman, not specifically Greek, practices. This is of course most evident in the cult of the Emperor which existed in Corinth. (2) What is crucial here is what Paul and other Jewish Christians assume transpires in a pagan temple. It is doubtful that Paul had ever gone into any of the pagan temples in Corinth and analysed what was happening. His polemics are based on his beliefs grounded in the Hebrew Scriptures, and on things he may have heard from others, but not on some sort of definitive study of pagan religion. It may be worth adding that Roman religion, while it adapted and adopted various aspects of Greek religion, was in fact seen as 'barbarian' by true Greeks.

${ }^{11}$ The Old Testament Pseudepigrapha Vol. 1, 347. In this he is simply following the older Greek edition of the oracles, cf. J. Geffcken, Die Oracula Sibyllina (Leipzig, Hinrichs'sche Buchhandlung 1902) 31. 
disprove the thesis set forth above, either by its context or its content.

There is one further reference to $\varepsilon \dot{i} \delta \omega \lambda$ ó $\theta v \tau$ ov which likely comes from the first century $\mathrm{AD}$, and it is found in the Didache. I quote the passage in full (Didache 6:3): 'And concerning food, tolerate what you are able, but keep well away from $\varepsilon i \delta \omega \lambda$ ó $\theta v \tau o v$; for it is the worship of dead gods ( $\dot{\alpha} \pi \mathrm{o}$

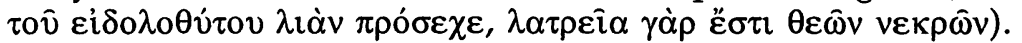
Here a clear contrast is made between eating whatever one is able to when it is simply a matter of food, but abstaining from $\varepsilon i \delta \omega \lambda$ ó $\theta v \tau$ vov because it is the worship of dead gods. The issue, then, is not merely food as in the first half of the exhortation but specifically food eaten in a context where it entails and is an expression of the worship of dead gods-i.e. in a pagan temple. There is nothing in any of these references to dispute the thesis that $\varepsilon i \delta \omega \lambda$ ó $\theta v \tau$ ov means meat consumed in the presence of an idol, or at least in temple precincts where the god's power and presence was thought to abide. 12

\section{Making a Sacrifice}

It will be worthwhile to make a short digression here, and explain briefly what the procedure was when one offered a sacrifice in Roman religion, and then ate some of the sacrificial meat. While there were of course variations from one temple to another, and from the worship of one god to another, there is enough of a general pattern that we can describe the common features of the ritual that was involved in Roman worship. ${ }^{13}$

First of all, ancient temples were in many ways the opposite of modern churches or synagogues in that the 'business' of religion took place outside the temple. Inside a pagan temple there was a central walled room (the cella) in which stood the statue of a god, sometimes decorated with

12The statue of a god was seen in Roman religion as the visible sign of the god's presence, not as the god itself. To eat in the presence of the image was to eat in the presence of the god-hence from Paul's point of view, at least implicitly, it was an act of idolatry. Notice that Paul accepts that idols themselves are nothing, but he believes a spiritual being stands behind them and is represented by them-i.e. a demon. Paul of course uses the term daimon to mean an evil spirit, but in a Greco-Roman context it simply meant a supernatural being or spirit of some sort.

${ }^{13}$ In this description I am following R.M. Ogilvie, The Romans and their Gods in the Age of Augustus (New York, Norton \& Co. 1969) 44ff. 
jewels and other gifts of devotees, such as flowers. Usually there was nothing else in this room except perhaps an incense altar; there were no seats or other furniture.

When a Roman wanted to secure the good will of a god, he would make a vow, usually written on a wax or possibly a lead tablet, and would go to the temple to arrange a time with the custodian when he could come and have a sacrifice offered on his behalf. This required arranging for the professional officials who actually cut the animal's throat to be present as well as for a flute player. There were set fees for such services, and apparently there was also a list of what animals the god of a particular shrine would accept (cf. CIL. 6.820 on all this). The one almost universal rule was that male gods required male animals to be sacrificed to them, and female gods required female ones.

When the day arrived for the sacrifice, the Roman in effect made his vow by entering the cella or central room, attaching the tablet to the statue of the god, and then praying facing the statue, lifting up his hands in supplication. While there are a few sanctuary sacrifices mentioned from time to time in the Roman literature of the period, ${ }^{14}$ in the vast majority of cases sacrifice took place outside and in front of the temple, the sacrificing being carried out on a stone altar there, if a blood sacrifice was involved. Next, the sacrificial animal was led to the altar on which a fire had already been built. Care was taken that no strangers, foreigners, or in some cases no non-Romans were present to contaminate the proceedings. 15

It is thus possible that Paul may have seen the act of pagan sacrifice from afar, but he would probably not have been allowed to scrutinise the process closely much less what followed in the temple or its adjacent buildings thereafter. The worshipper would normally invite family and friends to the sacrifice, not least because there would be a good deal of meat to be eaten up, and only the most wealthy of Romans had meat as a regular part of their diet. It was a luxury item, for the most part (cf. Tacitus, Ann. 14.24). The common person during the Empire only had meat at the occasional festival or public

\footnotetext{
${ }^{14} \mathrm{Cf}$. Festus, 356L.

${ }^{15} \mathrm{C}$. Plutarch, Roman Questions, 60, describing how women and dogs were excluded from sacrifices to Hercules and Mars; $c f$. Servius, On the Aeneid, 8.172 .
} 
sacrifice, and so for this reason too a sacrifice was a special occasion for a family.

Perhaps the first rule was that for the one offering the sacrifice had to come with clean hands and clean clothes, as was also true of the officials performing the rite. Indeed, a great deal of stress was placed on cleanliness. The ancient Roman could certainly have agreed with the sentiment 'cleanliness is next to godliness'. The Roman writer Livy (45.5.4) puts it this way: 'Every sacrifice is introduced by the statement that those with unclean hands should depart'. At the moment of sacrifice silence was commanded, 16 except for the sound of a flute player whose music was meant to drown out any background noises. Then the priest covered his head with the top folds of his toga (cf. 1 Cor. 11). After he had sprinkled flour between the horns of the animal and on the sacrificial knife, which was sometimes followed by pouring wine over the animal's head, the animal was stripped of whatever festive ribbons it might have, and a carefully written out and rehearsed prayer was said. Then the animal was stunned with a blow to the head by a hammer wielded by the priest's assistant (popa), and the knife man (cultrarius) slit the animal's throat. There are, according to R.M. Ogilvie, occasional references in the literature to the priest tasting the blood. 17

If all went well up to this point, the animal was dismembered and disembowelled, and the entrails were carefully inspected. Any blemish or fault found would invalidate the whole ceremony. It was these organs which would be cut up into pieces and put on the altar for the god to consume, the flames in fact doing the work here. It was quite rare for the whole carcass of the animal to be burned. Normally, most of the meat would be cooked quickly in the temple kitchen, with the priests and staff getting a portion and the family and friends the rest, and it would be eaten in a dining room (cenaculum) adjacent to the Temple. Needless to

16In state sacrifices this involved the cry 'favete linguis' 'check your tongues'! This may have some bearing on the commands to silence in 1 Cor. 14; $c f$. my forthcoming socio-rhetorical commentary on 1 and 2 Corinthians, Conflict and Community in Corinth, (Grand Rapids, Eerdmans 1994).

17Ogilvie, Roman Gods, 49. I have not as yet been able to trace these references. 
say, a person who went through this sort of ceremony and then ate the meat in the temple precincts was consuming meat in a very different context from one who simply bought meat in the macellum and ate it at home. In the former case eating, like the consuming by the god of its portion, was in fact the successful climax of the act of worship.

It is of course true enough that these temple dining rooms were the restaurants of antiquity, where friends might be publicly invited to dine, and in the case of the wealthy this may have happened with some regularity. But it is doubtful that a person invited to a meal which followed such a sacrifice would ever have seen it as a purely secular venture. There is even some evidence of the statue of the god being brought out to dine with the celebrators, and the very wording of some of the invitations to such feasts suggest the presence of the god is assumed while dining. For example in Papyrus Köln 57 we hear 'the god calls you to a banquet being held in the Thoereion from the ninth hour'. As G.H.R. Horsley says:

Although it was a matter of some disagreement earlier in the century, there is now a clear consensus that these banquets had a fundamentally religious character: Sarapis was considered as being present for the dinner. . This point is further supported by some extant coins from Alexandria and Egyptian terracotta which portray Sarapis reclining on a couch. ${ }^{18}$

Accordingly, I must reject W. Willis' interpretation that some of the meals in the temple precincts were basically secular in character. ${ }^{19}$ Even when a club (collegium) or society, or trade guild held a meal in the temple precincts this would have been preceded by a specific sacrificial event of worship as described above. So far as I can tell from the classical sources, while temple staff might turn extra meat over to a shop owner in the macellum, after which it could be sold and eaten at home, there is no evidence of temples simply keeping quantities of meat ready to hand in the precincts for basically secular banquets. A

\footnotetext{
${ }^{18}$ G.H.R. Horsley, New Documents Illustrating Early Christianity, I (North Ryde, Macquarrie University 1981) 5, 6, 8.

${ }^{19} \mathrm{~W}$. Willis, Idol Meat in Corinth. The Pauline Argument in 1 Corinthians 8 and 10 (Chico, Scholars Press 1985) 63.
} 
sacrifice, and thus an act of Roman worship with vows would have preceded even a club's dinner party. ${ }^{20}$

\section{The New Testament Evidence}

We now come to the New Testament references, and we will treat them in chronological order: 1 Corinthians 8-10, followed by the references in Acts 15 and 21, and then the references in Revelation 2. 1 Corinthians $8-10$ is dealing with an issue brought up in the Corinthian letter, as the quotation of the Corinthian position in 8:1 shows. ${ }^{21}$ The issue is $\varepsilon \dot{i} \delta \omega \lambda$ ó $\theta \tau$ zov but, as a careful reading of the chapter will show, after quoting various Corinthian slogans which were used as justification by the strong for their behaviour Paul comes to the nub of the argument in 8:10: 'But if others see you, who possess knowledge eating in the temple of an idol, 22 might they not, since their self-understanding is weak, be encouraged to the point of eating $\varepsilon i \delta \omega \lambda$ ó $\theta v \tau o v$ ?' The scenario is that the strong, in order to demonstrate that they had knowledge that idols were nothing, were participating in idol feasts and trying to encourage Christians who had scruples about such things to follow suit. ${ }^{23}$

This explanation not only makes good sense of 1

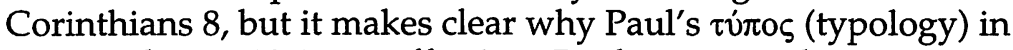
1 Corinthians 10 is so effective. Paul cites Exodus 32:6 in 1 Corinthians $10: 7$ as a prototype of the behaviour now going on

${ }^{20}$ It is doubtful that the modern distinction between sacred and secular is applicable to the 1st century AD in any case.

${ }^{21}$ However, see M.M. Mitchell, Paul and the Rhetoric of Reconciliation (Tübingen, J.C.B. Mohr 1991) 3 n.7 and her article 'Concerning MEPI $\Delta \mathrm{E}$ in 1 Corinthians', NT 31 (1989) 229-56 for the view that $\pi \dot{\varepsilon} \rho \imath$ $\delta \dot{\varepsilon}$ is no more than a topic marker, and not necessarily an indicator of a reference to an issue brought up by a correspondent.

22Since neither eating nor sacrifice normally took place in the sanctuary of the god itself, it is probable that Paul is here referring to the temple's adjoining dining rooms, where people would recline on couches to eat. The reference to the 'table of demons' (cf. 1 Cor. 10:20-21) probably suggests that in Paul's mind dining in the temple dining room was itself putting oneself into the presence of demons, whether or not one was actually present for the preceding rituals and sacrifice.

${ }^{23}$ It is interesting that in classical Greek literature $\varepsilon \dot{i} \delta \omega \lambda$ ov means a phantom or ghost (see Homer, Il. 5:451, Od. 4:794; Herodotus, 5.92). It is thus conceivable that the association in early Christianity between idols and demons, or idols and Satan in part was a result of this basic sense of the term. 
in Corinth: participating in pagan worship, eating meat in a pagan temple, and engaging in (sexual) play. We may suggest that Paul is not simply polemicizing against participating in dinner parties that were held in the temple precincts or adjacent dining areas (which would perhaps involve a brief ceremonial invocation but not full pagan worship). The Exodus citation in 1 Corinthians 10:7 clearly has full-fledged idolatry in view, and 10:14 is equally explicit: Paul does not merely say 'do not eat in dining areas adjacent to pagan temple precincts', but 'flee the worship of idols ( $\left.\varepsilon i \delta \omega \lambda \mathrm{o} \lambda \alpha \tau \tau^{\prime} \alpha\right)^{\prime}$ '. He then proceeds to talk about the act of pagan sacrifice (v. 20), and the partaking of the cup and table of demons (v. 21).24

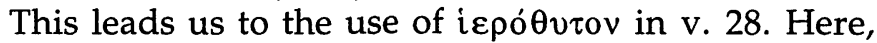
very clearly Paul is talking about a setting different from a pagan temple. The discussion has been prefaced with the advice to eat whatever one finds in the macellum (not in the temple), and then Paul proceeds to discuss what one should do if invited to a meal by an unbeliever. The setting here is surely in the home. What does one do, however, if someone says 'this

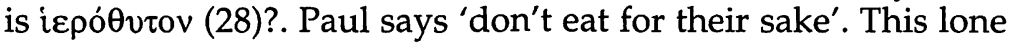

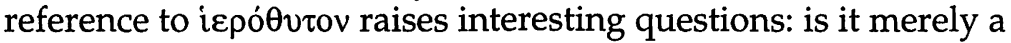
matter of Paul putting the correct term on a pagan's lips? I doubt this, not least because it is hard to imagine why Paul should think a pagan's conscience would be violated by a

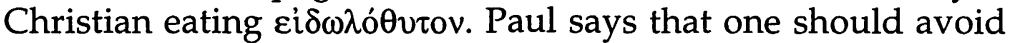
eating for the other person's sake. In light of the previous discussion in 1 Corinthians $8-10$ where the other person who is having problems with his or her conscience is a weak Christian, it is quite likely that that is the case here as well. It is the weak Christian who has also come along to this meal, not a pagan host, who would be likely to raise such an objection. It should not be objected that the weak Christian would not come to such a meal since he knew that temple meat would be consumed. Eating meat was a luxury in antiquity which only a minority could regularly afford, except when there were festivals and the like. Undoubtedly there were many meals served where meat was not a part of the dining fare. There is thus no implausibility in a weak Christian going to such a meal,

${ }^{24}$ I deal with this matter in much greater detail in my forthcoming Conflict and Community in Corinth (Grand Rapids, Eerdmans 1994). 
especially if he did not know the menu in advance. ${ }^{25} \mathrm{I}$ thus

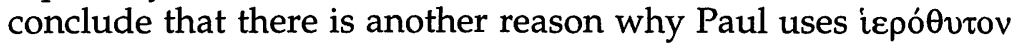
here on the lips of a Christian: in his view this is the proper term for food that has come from the temple, but is not being eaten in the temple or as part of temple worship. This interpretation makes sense in the context of the whole passage which is a discussion about the strong believer and the conscience of the weak Christian, not simply the conscience of just anyone.

This leads to the notoriously difficult material in Acts 15, and I do not propose here to enter the lists of the discussion of the various text forms of the Decree. I will simply assume that the majority of scholars are correct that the Decree includes

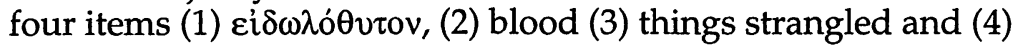
$\pi$ opveia (v. 29). All too often in the debate over the decrees a very important phrase is overlooked in the first reference to James' ruling in verse 20 . What he initially says is make sure the Gentiles abstain from $\tau \hat{\omega} v \dot{\alpha} \lambda \imath \sigma \gamma \eta \mu \alpha \dot{\alpha} \omega v \tau \hat{\omega} v \varepsilon \dot{i} \delta \omega \dot{ } \lambda \omega v$, $\pi$ opvei $\alpha$, and things strangled, and blood. This first phrase is curious if the issue is simply avoiding meat that has been sacrificed in a temple but is to be eaten elsewhere. The most natural way to interpret 'abstain from the pollutions of idols' is surely that he is referring to what happens when one is in the presence of idols. It is idols and their worship that are the pollutants here, affecting, as verse 29 makes clear, the meat which is sacrificed to them and hence those who consume it in such a setting. Gregory of Nyssa had no doubt about what this phrase refers to-' the pollution around the idols, the disgusting smell and smoke of the sacrifices, the defiling gore about the altars, and the taint of blood from the offerings' 26

I submit that it is the wrong question to ask where one might find a ruling in the Hebrew Scriptures about this or that item in the degree. The term $\varepsilon i \delta \omega \lambda$ ó $\theta v \tau o v$ is never used in the LXX at Genesis 9:4 (don't eat flesh with blood in it), or Leviticus 3:17 (don't eat fat or blood), or Leviticus 17:10-14 (don't eat blood, or [by implication] flesh with blood in it). These texts are not specifically about food partaken in an act of idolatry; and

\footnotetext{
${ }^{25}$ On meat as a luxury item $c f$. R. Macmullen, Paganism in the Roman Empire (New Haven, Yale University Press 1981) 34-42 and the notes.

${ }^{26}$ Vita Greg. Thaumaturg. PG 46:944. I owe this reference and its translation to Macmullen, Paganism, 40, as the primary text was not available to me at the time.
} 


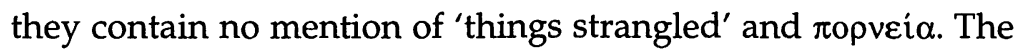
regulations to be followed by Noah are not identical in content, and certainly not identical in intent, with the Apostolic decree. I suggest that the proper thing to ask about the Decree is, where would one find all four of these items being partaken of in one place. The answer is probably in an act of pagan worship. 27 It is the context where these four items could most obviously be found together. We should have paid more attention to Acts 15:20: James is indeed inveighing against the pollutions of idols' and hence idol worship and its various related activities. 28

This interpretation makes perfectly good sense of Acts 15:21 - it is of course idolatry which Moses and the law most objects to about pagans, as the first two commandments of the ten make especially clear. The point is not to give Jews in the Diaspora synagogues the opportunity to complain that Gentile Christians are after all still committing idolatry in pagan temples in violation of the laws of Moses. ${ }^{29}$ Acts 21:25 does not conflict with this conclusion. There Gentiles and Gentile behaviour (cf. Acts 15:19) are once again the issue. If the issue had been abstaining from non-kosher food in a Christian meal, one would have expected these passages to look somewhat different. There is no hint here that table fellowship between

27 I am not here trying to argue that $\pi$ opvei $\alpha$ was an everyday occurrence in pagan temples. The point is just that Jews and Christians perceived such things to happen there regularly. If one wishes to argue that $\pi$ opvei $\alpha$ in Acts 15 has its basic Greek meaning of prostitution, then one may have to reopen the discussion about whether so-called sacred prostitution had in fact been revived, perhaps on a smaller scale, in the temple of Aphrodite in Corinth. Strabo's statement (8.6.20) mentions the practice of sacred prostitution in the Aphrodite temple as happening during the classical period, and then proceeds to say that there was still a small Aphrodite temple in Roman times. What he does not say is that the practice of prostitution was not continued in Roman times.

${ }^{28}$ The odd member in the decree is 'things strangled', since this was not a normal Roman or Greek sacrificial practice. Yet it must be remembered that if the Decree is historically authentic, it was given by a Jewish Christian who so far as we know never left the Holy Land and who may well have been familiar with a variety of other sorts of pagan practices besides those of the Romans.

${ }^{29}$ Here and elsewhere in this article I owe a debt to my mentor of some years, G.D. Fee; cf. his The First Epistle to the Corinthians (Grand Rapids, Eerdmans 1987). 
Jewish and Gentile Christians is the issue; it is rather a matter of specifically Gentile behaviour. James notes in 15:29 that these Gentiles are 'turning to God'. This stereotyped phrase indicates what they are turning to, the Decree refers to what they are turning from. James is urging, as does Paul, a clean break with the pagan past. Paul puts it quite clearly in 1 Thessalonians 1:9 '... you turned to God from idols ( $\left.\varepsilon i \delta \omega^{\prime} \lambda \omega v\right)$, to serve a living and true God'.

Our next text to look at is in Revelation 2:14 and 20. Here the Seer warns against the teachings of 'Balaam' and the prophetess 'Jezebel'. The latter is associated with the 'deep things of Satan'. Two things are being warned against$\varepsilon i \delta \omega \lambda$ ó $\theta v \tau$ ov and $\pi$ opvei $\alpha$. It is also noteworthy that the Seer associates following the teachings of Balaam with stumbling ( $\sigma \kappa \alpha \dot{v} \delta \alpha \lambda o v, v .14$ ), which is precisely what Paul is warning against in 1 Corinthians 8-10. Again the question to be asked is not where one might find $\varepsilon i \delta \omega \lambda \theta^{\theta} \theta \tau$ ov and $\pi$ opveí $\alpha$ separately but where one might find them together. Revelation 2:13 which speaks of Satan's throne is normally, and I would say rightly, thought to be an allusion to the notable pagan temple at Pergamum built to Augustus in 29 BC. For the author of Revelation an emperor who expected worship was indeed 'the great Satan', to borrow a familiar phrase, and emperor worship was an example of idolatry at its worst. I would suggest, then, that Revelation 2:14-15 is to be interpreted in the same way as the other New Testament references-as a warning against participating in pagan idolatry which entailed not only idol meat but also, from a Christian point of view, immorality. The reference to the 'deep things of Satan' seems to allude to what one was being enticed to find out about by participating in pagan worship. ${ }^{30}$

It is interesting as well that if one takes a spot check of some of the early Christian literature where $\varepsilon i \delta \omega \lambda$ ó $\theta v \tau o v$ appears, various authors understand that the discussion has to do with idolatry, and in particular eating in pagan temples. We have already noted the example cited above from the writings of Gregory of Nyssa, but two others can be mentioned here in brief. In the Homilies attributed to Clement of Rome (7:8-1-2)

${ }^{30}$ This is of course John's polemical way of putting it; no doubt a pagan would have said 'come learn about the deep things of the gods (or the $\operatorname{god}^{\prime}$ ). 
the author makes clear that he understands $\varepsilon i \delta \omega \lambda \theta^{\prime} \theta v \tau o v$ to entail partaking in the 'table of demons'. John Chrysostom in his Homilies on First Corinthians is quite clear that $\varepsilon \dot{i} \delta \omega \lambda$ ó $\theta v \tau o v$ is not meat eaten in a non-idolatrous context. Of this latter sort of meat (i.e., meat eaten outside a temple) he says at the beginning of Homily 20 on 1 Corinthians that Jesus' words in Matthew 15:11 apply: 'not the things that enter in defile a person. ..' No, says Chrysostom, the problem was partaking of the table of demons: $\varepsilon i \delta \omega \lambda$ ó $\theta v \tau o v$ was a matter of things offered in sacrifice to idols 'and the thing was becoming a way to idolatry'. Again, commenting on 1 Corinthians 8:4 he says Paul means 'one ought to abstain from this kind of banquet'. Chrysostom's remark on 1 Corinthians 8:8 is to the effect that the issue is about people getting used to the idol and eating in its presence. The problem with the weak is not merely that they have scruples about food from a temple but rather 'they still tremble at idols, Paul says'. His comment on 1 Corinthians $10: 10$ is to the same effect. Chrysostom's comments on the relevant texts in Act 15 are that they have to do with 'the pollutions of idols'. It is of course true that some of the Church Fathers did not read the New Testament passages on

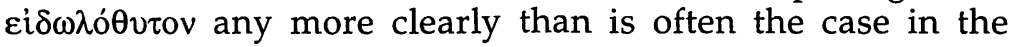
twentieth century, but some of them understood the implications quite clearly. It was the age-old issue of the temptation to idolatry, much as it is summed up in Exodus 34: idol altars are to be destroyed since God's people are to worship only one God and one is not to make a covenant with pagans 'for when they prostitute themselves to their gods and sacrifice to their gods, someone among them will invite you, and you will eat of the sacrifice' (v. 15). It is this material, and not the laws about keeping kosher that surely lies behind 1 Corinthians 8-10, Acts 15 and 21, and Revelation 2, and probably behind all other first century references to

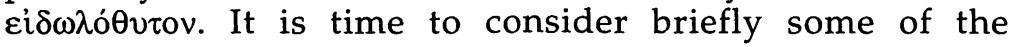
implications of this for New Testament studies.

\section{A Riposte about a Repast}

The first conclusion one can draw from the above study is that if Acts 15 provides a summary of a policy of the early Church 
enunciated by James, 31 then James was not imposing Jewish food laws on Gentiles, but prohibiting participation in idol feasts and their attendant activities. It had to be made clear, so long as the church still had hopes of having a witness to Jews in the Diaspora synagogues, that Christianity in no way sanctioned idolatry. Refuting the claim that worshipping Jesus as Lord was idolatry was difficult enough without adding the further problem of a continuing practice of traditional pagan idolatry by church members. This will suggest that James was not, as he has sometimes been portrayed, as conservative as the militant Judaizing wing of the Jerusalem Church, but quite close to Paul's view in this matter. ${ }^{32}$ Secondly, it seems likely that Paul certainly did accept the mandate given by James, and one can see how he proposed to implement it by reading 1 Corinthians 8-10 carefully. It is a mandate that was apparently applied in the Johannine churches in Asia Minor as well, to judge from Revelations 2. Thirdly, if the Council in Acts 15 is not about Gentiles keeping a basic minimum of Jewish food laws, but rather about not imposing circumcision on Gentiles (cf. Acts 15:5), or any other ritual requirement except the moral requirement of avoiding idolatry, then we may be better able to clarify the sticky relationship between what is recorded in Galatians 2 and Acts 15. On this last issue one could read the evidence in one of three ways:

1. Galatians is an early letter, indeed probably Paul's earliest among the canonical letters, written prior to the Acts council when the issue of Gentiles keeping food laws was still unsettled, hence the problem in Antioch recorded in Galatians $2: 11-14$. Surely the natural way to read the sequence of events in Galatians 2 is that it records first a journey (the second) up to Jerusalem by Paul to meet privately with the 'pillars', where the decision not to impose circumcision and the endorsement of the Gentile mission were agreed on privately amongst the leaders but not the issue of table fellowship. After this there was a crisis in Antioch when Peter came there and 'certain ones from

31The historicity of the occasion can of course be debated: see now C.C. Hill, Hebrews and Hellenists (Minneapolis, Augsburg-Fortress 1992). We are simply assuming the harder position at this point, that is, that it does accurately summarise a historical occasion.

32This is one of the more salient conclusions in Hill's book, with which I concur. 
James' showed up, resulting in a withdrawing from table fellowship by the Jewish Christians. This could happen because no public council such as is described in Acts 15 had yet transpired, and table fellowship had not been the burden of the first private discussion between Paul and the 'pillars'. It is possible, but unproveable, that Acts 11:29-30 refers in very summary fashion to the visit that Paul records in Galatians 2. In favour of such a correspondence is that: (a) the reference to Paul and Barnabas together suits Acts 11 as well as Acts 15; (b) Paul says he was to remember the poor (i.e. in Jerusalem and Judea) in Galatians 2:10, which is what Acts 11:29 is about in any case; (c) both Acts and Galatians concur that thus far Paul had only taken two trips up to Jerusalem since his conversion; (d) the fact that Paul and Acts say that the trip to Jerusalem by Paul and Barnabas was in response to revelation. Paul does not say in Galatians 2:2 that he had personally received this revelation and so it does not conflict with Acts 11:28.

2. We may simply discredit Acts as a source of historical information. I leave this option aside since it would simply mean we can learn nothing from it about the thorny problems discussed in 1 Corinthians 8-10 or Galatians 2.

3. The only other real way to read the data, if I am right about

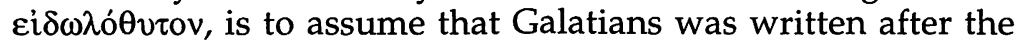
Decree and that Peter and Barnabas, despite the decree, which at least implied no imposition of Jewish food laws on Gentiles, succumbed to pressure from the militant circumcision party in Jerusalem, even though they knew no food laws were to be imposed on Gentiles. This would explain why Paul charges them with hypocrisy.

A variant of this last option has been offered by Craig Hill in his important new book Hebrews and Hellenists. ${ }^{33}$ He may be right that the issue at stake in Antioch was not Gentiles keeping Kosher, but rather Jewish Christian obedience to the Law. James had made no decree about this latter subject, the decree was quite explicitly addressed to Gentiles, and so the issue of Jews and Gentiles eating together was left unresolved. To Paul it was clear that since Christians must share in table fellowship, then Jewish Christians must not insist on keeping kosher on such an occasion. To others, such as the circumcision

33Minneapolis, Augsburg-Fortress 1992. 
party, this was not clear at all. In any case Paul is appealing to what was agreed on in Jerusalem and against Peter and Barnabas' behaviour because to him the implications of the agreement were quite clear. ${ }^{34}$

On the whole the first option mentioned above makes better sense of all the data and explains why it is that Paul is so much on the defensive in Galatians-the big issues had not yet been publicly settled and declared, whatever private accords had been made amongst the leaders. Paul had not yet been publicly endorsed by the Jerusalem church in his mission to the Gentiles. ${ }^{35}$ In any event, Paul's riposte about the repast that the 'strong' wanted to take part in is substantively the same as the Acts Decree 'flee idolatry'.

What a careful study of the relevant data shows is that the more one knows about the archaeology of Roman Corinth, the religious practices of the Greco-Roman world, and the contexts and likely meaning of the term $\varepsilon i \delta \omega \lambda$ ó $\theta v \tau$ ov in the 1st century $\mathrm{AD}$, the clearer Paul's (and James') advice about avoiding feasts in pagan temples becomes. Ei $\delta \omega \lambda$ ó $\theta v \tau o v$ was a polemical Jewish-Christian term, possibly coined by Paul himself or perhaps by James before him, to warn against the danger of participating in feasts in pagan temple dining rooms and thus placing oneself in the presence of malevolent supernatural beings that were not by nature gods, but nonetheless were believed to be both very real and spiritually dangerous to the Christian converts. In this light, none of the NT passages we have been discussing could be said to be 'idle

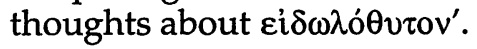

\footnotetext{
34It is right to note that of course Gentiles could eat with Jews, if the meal was a kosher one served on Jewish terms. This however is not the issue in Antioch as is made clear by Pauls' reference to Peter already living like a Gentile, which surely implies eating without regard to keeping the food laws.

${ }^{35}$ What follows here appears in a more extended and somewhat different form in my forthcoming commentary on 1 and 2 Corinthians entitled Conflict and community in Corinth: a Socio-rhetorical Commentary on 1 and 2 Corinthians (Grand Rapids, Eerdmans 1994).
} 